\title{
Dr. Fleming HLHI-ko Irakasleen prestakuntza beharren diagnosia eta horri buruzko hausnarketa
}

Maritxu Arostegi Escribano

Dr. Fleming HLHI (Villabona)

DOI: $10.1387 /$ tantak.15551

GAKO-HITZAK: Ikerkuntza-Ekintza, prestakuntza, hausnarketa, kolegialitatea, Haur eta Lehen Hezkuntza.

\section{SARRERA}

Nire ibilbide profesionalean zehar, bai aholkulari, bai ikasketaburu gisa, irakasleen prestakuntzaz arduratzea egokitu izan zait eta, tutore gisa, nik jasotako prestakuntza praktikara eramateko kezka. Prestakuntzaren alorrean, nahiz eta ahalegin handiak egiten diren, aurrerapausoak espero zitezkeen baino txikiagoak dira eta horrek zenbait galdera sorrarazten dizkit: zerk oztopatzen du aldaketa? Zertan prestatu behar dugun ba al dakigu? Zeinek erabaki behar du? Edozein prestakuntza motak balio al digu?

Galdera hauen erantzuna bilatzea interesgarria bezain baliogarria da, gizartean azken urte hauetan bizi izandako aldaketak oso sakonak izan baitira, eta, horren ondorioz, irakasleriaren prestakuntzaren inguruan, beste zerbait egin beharko litzateke, baldin eta XXI. mendeko beharrei erantzun nahi badiegu, eta gure ikasleak eskakizun maila horretara egoki molda daitezen prestatu nahi baditugu, hori baita hezkuntza-sistemak gure eskolatik espero duena (EHAA zk 72).

Gizarte tradizional batetik moderno batera pasatu gara, eta hau da horren ezaugarri nagusia: aldaketa esanguratsuak eta azkarrak gertatzen direla (Aguerrondo eta Xifra, 2002, Perrenoud, 2012). Gure garaiko gizarte honi informazioaren gizartea, ezagutzaren gizartea edo ezagutzaren ekonomia ere baderitzote (Pérez Gómez, 2006) eta ez du zerikusirik duela 30 urteko gizartearen bizimoduarekin. Hori dela eta, urteetan zehar garatu dugun hezkuntza-sistemak aldaketa esanguratsuen beharrean dago (Aguerrondo eta Xifra, 2002) eta ikasleak aldakorra, konplexua, eta etorkizun ezezagunekoa den gizarteari aurre egiteko prestatzea da erronka nagusia; horretarako, curriculumak irekia, malgua eta egoera errealetan, konplexue- 
tan zein problematikoetan oinarritua izan behar du (Pérez Gómez, 2010). Horrek guztiak eragin zuzena du irakaslearengan eta haren prestakuntzan, bera ariko baita ikasleekin etengabeko elkarrekintzan, berak garatu behar baitu curriculuma, metodologia aukeratu, baliabideak erabili, aniztasuna kudeatu... Irakasleok gauzak beste era batera egiten ikasi behar dugu eta horrek ohikoa ez den prestakuntza eskatzen du.

Gai honetan adituak diren autoreek (Stenhouse, 1985, 1987; Elliot, 1989; Schön, 1992; Villar, 1995; Marcelo, 1995; Pérez Gómez, 1999, 2006, 2010; Imbernon, 1994, 2008; Contreras, 2010; Korthagen, 2010; Perrenoud, $2012 \ldots$ ) egindako ikerketetako emaitzetan oinarrituta diote irakasleen prestakuntzan biderik eraginkorrena praktikaren hausnarketatik abiatzea dela eta horretarako bidea ematen duen metodologia gisa Ikerkuntza-Ekintza aipatzen dute:

«Desde este sentido la investigación-acción se presenta como una perspectiva eficaz, que desde el propio profesorado puede ayudarle a encontrar respuestas a los problemas de la enseñanza, al tiempo que favorece un modelo de formación que permite llenar el vacío que existe entre la investigación y la práctica. También permite al profesorado la posibilidad de desarrollar sus habilidades en la toma de decisiones.» (Imbernon, 1994: 75.-76. or.)

Beraz, honako hauetara bideratuta dago lan hau: Ikerkuntza-Ekintzaz (I-E) baliaturik, Dr. Fleming ikastetxeko irakasleen prestakuntza beharren diagnostikoa egitea, hausnarketa bultzatzea, horretan sakontzea, ondo pentsatutako erabakiak hartzen laguntzea eta prestakuntza mota berri bati ekinez, hemendik aurrerakoari beste ikuspuntu batetik begiratzea.

\section{MARKO TEORIKOA}

Ikerketa objektua zera da, Dr. Fleming HLHI eskolako irakasleriaren prestakuntza beharren diagnostikoa egitea eta hori aurrera eramateko plangintza zehaztea, prozesu hori kalitatezkoa izan dadin, zaindu beharreko alderdiak irizpidetzat hartuz. Planteamendu horrek talde-hausnarketa eskatzen du eta aldaketarako bidea jorratzea du helburu. Horregatik, marko teorikoa garatzerakoan, paradigma sozio-kritikoa izango da erreferentzia nagusia.

Lehen urratsa informazioaren gizartearen ezaugarriak ezagutzea izango da; bigarrena, jakitea horrek nolako eskola eskatzen duen eta behar berriei erantzuteko nolako saiakerak egin diren; ondoren, irakasleen zeregina zertan datzan zehaztea; eta, azkenik, azaltzea kalitatezko irakaskuntza bermatzeko ezinbestekoa den prestakuntzak nolakoa behar duen izan. 


\subsection{Zertan aldatu da gizartea eta nolako erronkak ekarri dizkigu?}

Lehen aipatu bezala, azken urteotan gizartean bizi izan ditugun aldaketak oso sakonak izan dira eta oso bizkor gertatu dira. Pérez Gómezek (2006) eta Imbernonek (2008) azaltzen digutenez, informazioaren gizarteak honako aldaketa hauek ekarri dizkigu:

- Gizarte industrial batetik, industria-osteko ekonomia eredura pasatu gara, non ekoizpena baino, berrikuntza baita aberastasun-iturria, eta ekonomiaren helburua ideia berri bat besteek baino lehen kanporatzean datza. Abiadura, adimena eta berrikuntza dira gakoak. Ikaskuntzaren gizarte honek zer eta nola irakatsi/ikasi egin behar den birplanteatzera garamatza.

- Informazioa izugarrizko abiaduran ekoizten, banatzen eta kontsumitzen da. Gainezka egiten digun informazioak saturazioa, nahasteborrastea eta desinformazioa sortzen du; beraz, ezagutzara iristeko modua ere aldatu egin da (hautatu, balioztatu, eta erabakiak hartu) eta horrek bestelako gaitasun, trebetasun eta abileziak eskatzen ditu. Hori ikasgeletara eraman ahal izateko, aurretik, irakasleriak praktikatu behar du.

- Teknologian eta komunikabideetan gertatu diren aldaketa itzelek (informazio hori plataforma birtualen bitartez iristen zaigu, non espazio eta denboraren mugak desagertu baitira) norberaren eta instituzioen bizimodua eraldatu dute, eta, horren ondorioz, kinka larrian geratu da ezagutza transmititzeko betiko modua.

- Gizartearen garapen azeleratuak instituzioetan, bizikidetzan eta familia-ereduetan izan duen eraginak bizimodua, pentsamoldea nahiz sentitzeko eta jokatzeko erak eraldatu ditu. Ikasleen egoera aldatu da, eta haiekin jokatzeko ohiko erak ez du balio.

- Mugikortasuna gero eta handiagoa denez, gizarte kulturaniztun eta eleaniztuna sortu da eta hainbat ikasle mota ekarri dizkigu gure geletara. Horren eraginez, aniztasuna gure eskoletako ezaugarri garrantzitsu bihurtu da, eta hori kudeatzen ikasi behar da eta aberastasun-iturri bilakatu (Courtney, 2013).

Aldaketa horiek direla eta, garai batean eskolak arrakastaz betetzen zuen paperak ez du balio. Oraingo eskolaren zeregin nagusia ezin da, lehen zen bezala, informazioa transmititzea izan. Horren guztiaren jakitun dira Europan eta hezkuntza-sistema gaurkotzearen beharra (Europako Kontseilua. Lisboa, 2000) agertu dute. Egoera hori dela eta, Europako Parlamentuak (2006/962/EE Gomendioa), besteak beste, etengabeko prestakuntzaren beharra azpimarratzen du, eta, hori lortzeko, gazteek zein helduek lortu behar lituzketen oinarrizko 8 konpetentzia definitzen ditu. Norbanakoaren garapena, integrazio soziala, lana eta herritartasun aktiboa ziurtatzeko beharrezkoak diren ezagutza, gaitasun eta jarrera multzotzat hartzen di- 
tuzte konpetentzia horiek. Gomendioa eta konpetentzien ideia hartuta egin zen, Espainian, 2006ko LOE erreforma eta horri jarraituz osatu zen oinarrizko gaitasunak ardaztzat dituen Euskal Autonomi Erkidegoko curriculum berria arautzeko 2007ko urriaren 16ko Dekretua.

Hezkuntza-sistema gaurkotzea; beraz, ezinbestekoa da, baina hori nola egiten den oso garrantzitsua da. Espainian eta, horren ondorioz, Euskal Autonomia Erkidegoaren hezkuntzan, 1970etik gaurdaino, 12 lege organiko jarri dira indarrean, eta derrigorrezko hezkuntzak lau erreforma pairatu ditu. Azken bi erreformak 1990ean nahiz 2006an gertatu dira, eta bosgarrena izan daitekeena inposatzeko bidean dago. Ez al da gehiegi 25 urtetan 3 erreforma? Zergatik hainbeste aldaketa? Nondik dator horren beharra? Nolako emaitzak lortu dira? Zein ondorio ekarri ditu?

Gimenok (2006) esaten digunez, aldaketa horien guztien atzetik ez dago diagnostiko zehatz bat; erreformak ez daude zer aldatu behar den, zergatik, nola, nora joan behar den eta abar aztertu duen inongo ikerketatan oinarriturik, horiek indar politikoen arteko desadostasunetik eta botere txandakatzetik datoz. Erreforma bat benetan arrakastatsua izan dadin, lehenik eta behin, denon arteko gutxieneko adostasuna behar da (Puelles, 2006); eta bigarrenik, teoriatik, legeetatik, paperetatik..., alderdi praktikoan eragin behar du, dekretu huts batek ez baitu irakasleen pentsamoldeak, tradizioak eta praktikak aldatzen (Fullan, 1993; Diaz Tezanos, 2006). Hori gutxi balitz, bitarte horretan hezkuntza sistemako zuzeneko protagonistak diren irakasleei ez zaie inoiz egin beharreko aldaketen inguruko iritzia eskatu; ez dute aintzat hartu erreforma berri batek eskatzen dituen bestelako egiteko erak aurrera eraman ahal izateko beharrezkoa prestakuntza, hasierakoa zein iraunkorra (Puelles, 2006; Perrenoud, 2012; Imbernon, 2008); irakasleek zerbait aldatu bezain pronto, hori eten egin behar izan dute eta berria izan zaien beste zerbaitekin hasi; eta azkenik, porrota suertatuz gero, irakasleen errutzat jotzen da (Villar, 1995). Egoera horrek frustrazioa sortzen du eta datorrenarekiko mesfidantza (Gimeno, 2006). Imbernonek (1994) fenomeno horri desprofesionalizazioa, proletarizazioa edo deskualifikazio pertsonala deitzen dio. Hauxe da hortik atera daitekeen lehenengo ondorio: ohartzea irakasleriarekin kontatu gabe aldaketa nekez gauzatuko dela.

Beraz, aurrera egiteko, orain eskoletan dagoen lan egiteko erak eskakizun berrietara egokitu behar baldin badu, ikasleak, edukia jaso baino, konpetenteak izan daitezen prestatu behar baditugu, aldaketak sustatzeko lege edo erreforma berriak indarrean jartze hutsak funtzionatzen ez badu, eta irakasleok protagonismo handiagoa behar badugu, zertan eta nola eragin behar dugu?

Aguerrondoren eta Xifraren (2002) ustez, erreforma (formaren aldaketa) baino, paradigma aldaketa, eraldaketa (era batetik bestera pasatzea) behar da, baina horrek hezkuntza-sistema osoari egiten dio erreferentzia eta lan honetako helburutik urrun gelditzen da hori. Dena den, gure es- 
kutan egon badago eskola bat mikro-sistematzat hartzea eta han eragitea. Kasu horretan, eraldaketaren tokian, berrikuntza (ikuspegi berrietan oinarritutako eredu alternatiboen garapena helburu duen ekintzatzat hartuta) jarri beharko genuke, eta, horien bitartez, aurrerapausoak eman.

Hala ere, garbi eduki behar dugu paradigma-aldaketak ohiko egiteko era berritzea eta betiko ohiturak zein errutinak alboratzea eskatzen duela. Horrek irakasleengan segurtasun-falta eta beldurrak sor ditzake eta, horren ondorioz, erresistentziak eragin (Stenhouse, 1987; Villar, 1995; Aguerrondo eta Xifra, 2002; Imbernon, 2008).

Horiexek dira lan honetarako behar ditugun erreferentziak: berrikuntza eta hori gauzatzeko irakasleok behar dugun prestakuntzaren ezaugarrien azterketa. Lan hori arrakastaz burutuz gero, dagoen porrot-sentsazioa gainditzeko eta irakasleak indarberritzeko lehen urratsa egingo dugu.

\subsection{Zein dira irakasleen prestakuntzaren ardatzak?}

Fullanek (1993) egindako ikerketetan oinarriturik esaten digu ezinezkoa dela ikasleek etengabe ikas dezatela eta lankidetzan treba daitezela (ekonomiak aurrera egiteko gero eta espezializatuagoak diren lanpostuen arteko lankidetza ezinbestekoa bihurtu da), baldin eta irakasleek ezaugarri beren jabe ez badira. Hori dela eta, prestakuntzaren helburu nagusia aldaketa, hobekuntza, eta berrikuntza sustatzea dela jakinik (Imbernon, 1994), hona hemen irakasleen prestakuntzaren behar berriak garatzeko gakoak: etengabeko prestakuntza, gaitasunetan oinarritutako prestakuntza, hausnarketa, prestakuntzaren objektu aldaketa eta kolaborazioa nahiz kolegialitatea.

Ikasleek gizartean gertatuko diren aldaketa ezezagunei era egokian aurre egiten jakin dezaten, haien bizitza osoan zehar ikasten ikasteko prestatu behar ditugu, eta irakasleak gizarte bereko partaideak zein haien prestatzaileak izanik, ezin dira haiek baino gutxiago izan. Beraz, irakasleriaren etengabeko prestakuntza baldintza ukaezina da, baina nolakoa?

Lehen esan dugun bezala, gaur egungo prestakuntzaren ardatzetako bat gaitasunak dira. Bizitzan zehar edozein esparrutan suertatzen diren egoerei eta gatazkei ahalik eta erantzun egokiena emateko behar diren ezagutza, trebezia eta jarreren multzoari egiten dio erreferentzia konpetentzia edo gaitasun hitzak (Perrenoud, 2012; Zabala, 2012; Pérez Gómez, 2010). Konpetentziek, beraz, ikasitakoa egoera desberdinetara egokitzeko eta transferitzeko gaitasuna suposatzen dute. Hortaz, irakasleek beren lanbidearekin lotutako gaitasunak garatu beharko dituzte, egoerak ulertzeko, ikasteko, ikasitakoa egoeretara egokitzeko, berritzeko, berrikuntzaprozesuak komunikatzeko... (Imbernonen, 1994).

Horrek suposatzen du prestakuntza ezin dela edukietan oinarrituta egon, horien aplikazioan baizik, edukiak ikasteak ez duelako ikasitakoaren 
aplikazio egokia inondik inora bermatzen, eta, orobat, ikasitako teoria pertsona bakoitzak barneratuta dituen eskemen arabera aplikatzen duelako.

«No descubro nada nuevo si digo que el oficio docente se hace con uno mismo, con lo que uno es y lleva incorporado. Al enseñar, uno se expone, se enseña; no sólo enseña un saber, sino la propia relación con el saber; no sólo está allí, entre estudiantes sino que es ante todo presencia. Y esto es lo que primero perciben alumnos y alumnas: la presencia (o la ausencia), el modo de ser alguien que se muestra (o no) y entabla (o no) una relación, tanto con el propio alumnado como con lo que pretende enseñar, o compartir, o estimular e impulsar en esa relación personal». (Contreras, 2010: 64. or.)

Bizitzan zehar bizi izandakoak, pertsonengan, oso barneko balio, sentimendu, esanahi, beharrak... sorrarazten ditu eta horiek, konturatu gabe, gure jokaerak eta jarrerak gidatzen dituzte, arlo pertsonalean nahiz arlo profesionalean (Imbernon, 1994; Villar, 1995; Korthagen, 2010; Pérez Gómez, 2010). Barruko muin hori episteme (teoria) eta phronesis (praktika) munduen arteko etengabeko interakzioan osatzen da, ezagutza arrazionalaren zein esplizituaren eta emozioen, desiren, ohituren, erlazioen... artekoan, alegia. Arlo profesionalera eramanda, autore batzuek Gestalt deitzen diote barruko multzo horri; Schönek (1992), conocimiento en la acción; Imbernonek (1994) horien gauzatzeari, ezagutza arrunta; Pérez Gómezek (2010), pentsamendu praktikoa, eta Villar Angulok (1995), printzipio praktikoak.

Pentsamendu praktiko hori, beraz, inkontzientea da. Horrek esan nahi du gure lanean ditugun jokaerak inkontzienteak gidatzen dituela, batez ere bat-bateko erantzuna eskatzen duten egoeretan, eta maiz ez datorrela bat teorian ikasitakoarekin, Pérez Gómezen (2010) hitzetan kontrajarriak diren erabilitako teoriak eta adierazitako teoriak. Hori jakinda, gure prestakuntzan, ezinbestekoa izango da praktika, bizipenak eta testuinguru errealetako esperientziak ere kontuan izatea (Stenhouse, 1987; Pérez Gómez, 2010). Gaur egun gai horretan adituak diren autore guztiek, pentsamendu praktikoa lantzeko, ezinbestekotzat jotzen dute ezagutza pertsonalaren zein profesionalaren inguruko hausnarketa, hori ikasteko tresna bihurtzen baita. Stenhousek (1987) esan zuen bezala, irakasleon subjektibotasuna da benetako interesgunea eta ez objektibotasuna. Baina hori ez da nahikoa; Imbernonek (1994) esaten duenez, ezagutza arruntetik ezagutza pedagogiko espezializatura pasatu behar da eta, horretarako, hausnarketa praktikoa bezain garrantzitsua da hori zalantzan jarriko duten edo aztertzeko aukera emango duten edota baieztatuko duten elementu teorikoak izatea. Horren bitartez, lortuko dugu adierazitako teoriak Gestalt bihurtzea, eta, hala, ezagutza aberastea eta oinarrizko gaitasunak garatzea (Pérez Gómez, 2010). Gure prestakuntzan, teoriaren eta praktikaren arteko zubiaren beharra dago. 
Oraingo ikuspegiaren arabera, ikasleak gure jomuga direla ahaztu gabe, irakasleok bihurtzen gara aztergai. Prestatzea ez litzateke izango zer egin behar diedan ikasleei haiengandik zerbait lortzeko, baizik eta zer egin behar dudan eta nola jokatu behar dudan nik ikasleekin haiengandik zerbait lortzeko: «Formarse como docentes es necesariamente hacer algo consigo mismo» (Contreras 2010, 66. or.).

Norberaren praktikaren eta teoriaren inguruko hausnarketarako gaitasuna izango da irakasleon prestakuntzarako oinarrizko bigarren zutabea (Stenhouse, 1984, 1987; Schön, 1992; Imbernon 1994, 2010; Marcelo, 1995; Villar, 1995; Pérez Gómez, 2006, 2010; Contreras, 2010, Korthagen, 2010, Perrenoud, 2012).

Orain arte esandako guztia aintzat hartuz, prestakuntza eraginkorrak, beraz, honako hauek sustatuko behar lituzke: praktika, bizipenak, testuinguru errealetako esperientziak eta ezagutza pertsonala zein profesionalaren inguruko hausnarketa, eztabaida eta alderaketa (Villar, 1995; Pérez Gómez, 2010; Imbernon, 2008). Zeregin horretan, ikuspegi dialogikotik, berdinen arteko elkarrizketak garrantzi berezia hartzen du, truke horretatik ikasi egiten delako. Esanahiak etengabe eraiki eta berreraiki egiten dira norberaren esperientzietatik; eta besteekiko elkarrizketan nahiz eztabaidan balioztatzen dira (Valls, Soler, Flecha, 2008). Horixe da gaur egungo teorikoek norberaren alderdi praktikoarekin eta hausnarketarekin batera proposatzen duten prestakuntzaren hirugarren ardatza: kolegialitatea. Izan ere, taldeko erabakiak hartzeko tresna ere bada, honako hauek lantzeko aukera emateaz gain: hausnarketak zein lankidetza-lanak eta kolegiatuak ikasteko, egiten dugunari esanahia emateko, gure jarreren jabe izateko eta aldaketa sustatzeko. Maila pertsonalean gertatzen diren aldaketak ezinbestekoak diren arren, horiek taldearenak izatera iritsi behar dute, gaur egungo gizarteak beharrezkotzat jotzen dituen aldaketa horiek instituzionalizatzeko, sistematizatzeko (Stenhouse, 1987; Marcelo 1995; Imbernon, 2008) eta mikro-sistema gisa funtzionatzeko, hau da, lehen aipatutako berrikuntza gerta dadin.

\subsection{Nola gauzatu daiteke prestakuntzaren prozesua aurreko guztia aintzat hartuta?}

Orain arte esandako guztia kontuan hartuz, Fullanek (1993) esaten digunez, aldaketarako dinamikaren eragile bihurtu behar dugu, prestakuntza eraginkorra izan dadin eta nahi genituzkeen aldaketak benetan gauzatu daitezen, eta, horren ondorioz, prestakuntzaren zenbait alderdirekiko ikuspegia erabat aldatu behar da. Autoreek honako hau proposatzen dute:

- Norberaren prestakuntzatik zentroan bertan kokaturiko, eta, beraz bertako irakasle guztientzako prestakuntza izatera pasa behar da. 
- Irakaslearen eginkizunak pasibo (jaso) izatetik aktibo (eman) izatera pasatu behar du, eta horrek prestakuntzaren prozesuaren ikuspegi aldaketa eskatzen du.

- Zentro osorako prestakuntza beharrezkoa bada, irakasleen arteko adostasuna ezinbestekoa izango da.

- Prestatzaileen eginkizuna aditu izatetik gidatzaile izatera pasako da.

Ikusi dugunez, eskoletan, zentroetan, mikro-sistemetan eragitea da aldaketarako giltzetako bat. Irakasleak bakarka hartuta, haien prestakuntza ziurtatu behar da, baina hori ez da nahikoa; benetako aldaketa erabaki adostuen eskutik etorriko da, horrek izango baitu eragina antolaketan, curriculum ezkutua agertzean (Santos Guerra, 2010) eta berrikuntza sustatzean. Eskola bera aldaketarako eta prestakuntzarako oinarrizko unitate bihurtu behar dugu (Marcelo, 1995).

Lehen esan dugun bezala, aldaketa gure praktikaren hausnarketaren eskutik etorriko bada, prestatzeko, errealitatean ditugun egoeretatik abiatu beharko dugu, guk gure praktikan topatzen ditugun beharretatik eta gertutik gatazkatsu bizi ditugun egoeretatik (Stenhouse, 1984; Schön, 1992; Contreras eta Pérez de Lara, 2010). Proposamen hori, gutxienez, bi arrazoitan oinarritzen da. Batetik, gu errealitate horren eragile izanik, nahitaez, aldaketa gure benetako errealitatea ezagutu ondoren etorriko da; eta bestetik, egoera errealak aztertuta bertan topatzen ditugun benetako premiei erantzungo dion prestakuntza jasoko dugu.

Oraingo ikuspegitik, irakaslea hausnartzaile bihurtzen da, haren praktikaren ikertzaile, pentsalari kritiko eta autonomo (Stenhouse, 1984; Schön, 1993; Villar, 1995, Marcelo, 1995; Imbernon, 2008; Pérez Gómez, 2010; Contreras, 2010; Korthagen, 2010).

- Pentsalaria: haren praktika aztertzeko dagoen modu bakarra hausnartzea da.

- Kritiko: jokaera inkontzienteak kontziente egiteko era.

- Autonomoa: erabaki arrazoituak eta pertsonalak hartzeko gaitasuna.

Prestakuntzarako giltza hausnarketaren prozesua da, horren bitartez garatuko baitugu aldarrikatutako gaitasuna. Zenbait autore aztertuta, eta labur esanda, honako hauek dira prozesu horren urrats orokorrak:

- Aukeratutako esparruan egiten diren praktiketatik abiatuta, errealitatearen azterketa eta esperientzia-trukaketa.

- Handik sor daitezkeen zalantzei nahiz behar berriei erantzuteko behar den teorian sakontzea.

- Erabakitako aldaketak esperimentatzea.

- Esperientzia berri horien ebaluazioa, berriz ere praktikak aztertuz eta behar berriak detektatuz. 
Azken finean, prozesuaren eskema hausnarketa-ekintza (reflexión-acción) da. Stenhousek (1984) esaten zuenari jarraituz, autore gehienak bat datoz irakasle hausnartzailearen beharrarekin eta Villarrek honela definitzen du: «... el profesor reflexivo es aquel que tiene la capacidad para analizar su propia práctica y el contexto en el que tiene lugar, el que es capaz de responsabilizarse de su acción futura.» (1995: 63. or.). Baina prozesu horrek ezin du unean-unekoa izan, etengabekoa baizik, baldin eta gaur egungo gizarteak eskatzen duen etengabeko berrikuntza sustatu nahi baldin badugu: «Hoy más que nunca, ser maestro es vivir la necesidad de una permanente renovación» (Sancho eta Correa, 2013: 22. or.). Etengabeko berrikuntza hori sustatzeko, beraz, ziklikoa den prozesu hausnartzaile bat beharko dugu.

Ikuspegi honetan, ezinbestekoa da prozesu osoa taldean, elkarlanean eta kolegialitatean egitea, beraz, talde osoaren benetako interesak kontuan izatea eta adostutako egoera erreal eta gatazkatsuak izango dira abiapuntua. Hala, erresistentziak egon arren (prozesu horren ezaugarri arruntzat hartu behar dugu), inposatutako egoera batean baino txikiagoak izango dira eta aniztasuna aberastasun-iturri bihurtuko da (Schön, 1992; Imbernon, 2008). Ez dugu ahaztu behar horrelako prozesu batek eredu parte-hartzaile eta demokratikoa eskatzen duela, baita irakasleen inplikazioa ere. Irakasleon prestutasunik eta inplikaziorik gabe, nekez sustatuko dugu gure urteetako errutinen, ohituren, sinesmenen... aldaketa eskatzen duen jarrera (Stenhouse, 1987; Villar, 1995; Imbernon, 2008; Pérez Gómez, 2010; Korthagen, 2010).

Gure ikuspuntutik, irakasleek beren garapen profesionalaren jabe izatera iritsi behar lukete eta konpetentzia horixe bera eskuratu behar lukete. Beraz, prozesua, tresnak, antolaketa eta abar ohiko bideetatik aldentzen diren neurrian, ohiko prestatzailearen eginkizunak ere ez digu balio izango. Hala ere, helmugara iristeko prozesua ezezaguna eta luzea izan daitekeenez, bidea jorratzen lagunduko lukeen pertsona beharrezkoa suerta daiteke. Diagnostikatutako beharretatik aukeratutako egoera errealetan eta kolegialitatean oinarritutako hausnarketa-prozesuak gidatzea litzateke haren eginkizuna (Marcelo, 1995; Imbernon, 2008).

Orain arte esandakoa labur esanda, hona hemen zita hau:

«...la formación del profesorado no se apoya tanto en la adquisición de conocimientos teóricos de las disciplinas académicas y de competencias y rutinas didácticas, como en el desarrollo de la capacidad de análisis, indagación, reflexión crítica y procesamiento de la información para el diseño de proyectos en antes y durante la acción, superando el carácter individualista para compartir la reflexión con compañeros. Esto nos conduce a la formación y al desarrollo de un pensamiento práctico que se aprende en la reflexión y la auto-evaluación, en la práctica de forma colegiada y que se legitima en la puesta en escena en una praxis contextualizada. Y esta praxis contextualizada existe en los centros educativos como el importante espacio profesional del profesorado.» (Imbernon, 1994: 96. or.) 


\section{METODOLOGIA}

Ikerketa honek gure eskolako errealitatearen eraldaketa eta kolektiboaren emantzipazio progresiboa bilatu nahi du, eta, beraz, metodologia kualitatiboaren eta paradigma kritikoaren barruan, Ikerkuntza-Ekintzaz (I-E) baliatuko gara.

\subsection{Metodoa}

Ikerkuntza-Ekintzak ez du ezagutzak metatze edota errealitatearen azterketa hutsa bilatzen, baizik eta hauxe du helburu: hezkuntza praktikaren hobekuntza ekarriko duten erabakiak eta aldaketarako prozesuak gidatuko dituen informazioa eskuratzea. Beraz, Ikerkuntza-Ekintzaren lehen xedea, ezagutzak sortzea baino, praktika hobetzea da (Villar, 1995; Kemmis eta Netasgart, 1998; Sandin, 2003), betiere hori baieztatuko edo deuseztatuko duen teoriarekin alderatuta (Contreras eta Pérez de Lara, 2010; Imbernon, 1994) eta, hain zuzen ere, horixe bilatu nahi da ikerketa honetan, marko teorikoan, argi azaldu den bezala.

Beste alde batetik, talde-izaera, denok partaide sentitzea eta denen arteko erabakiak hartzea oso garrantzitsua da eztabaidatutakoa eta erabakitakoa esanguratsua izan dadin, jendeak berea senti dezan, talde gisa funtziona dezan eta, horren ondorioz, benetako aldaketak gerta daitezen (Kemmis eta Netasgart, 1989; Rodriguez, Gil eta García, 1996). Gainera, funtzionamendu horrekin, benetan hori guztia betez gero, partaideen inplikazioa areagotu egingo da, horixe bilatzen da eta horixe ahalbidetzen du Ikerkuntza-Ekintzak.

Aipatzekoa da ere I-Ek, ezinbestean, lan ziklikoa eta sistematikoa eskatzen duela. Elliotek (1989) azaltzen digunez, hauek lirateke zikloaren urratsak:

- Gaia aukeratzea: lankidetzan eta metodologia parte-hartzailea erabiliz, ikerketaren abiapuntua zein izango den erabakitzea da eman beharreko lehen pausoa.

- Planifikazioa: ondoren, kezkari heltzeko plan kritiko, informatua eta malgua diseinatzea dator.

- Planari ekiteko ekintza kritikoki informatua aukeratzea: praktikaren hausnarketaren ondorioz, behar bezala informatutako eta pentsatutako praktikaren aldaerari heldu behar zaio.

- Kritikoki informatutako ekintzaren ondorioei behatzea: praktikaren azterketarako oinarria izango den datua biltzean datza.

- Hausnarketa: ondorengo ziklo osoaren (gaiaren aukeraketa, planifikazioa, ekintzaren aukeraketa, praktikaren behaketa, hausnarketa) garapenerako oinarria izango den ondorio horien inguruko hausnarketa kolektiboa; esanahien berreraikuntza ekarriko du horrek. 
Baina esan bezala, ziklikoaz gain, sistematikoa ere izan behar du eta, hori ziurtatzeko, praktikaren behaketatik datuak jasotzea eta hausnarketa planifikatzeaz gain, parte-hartzaileen bestelako informazio biltzea bermatu behar da ikertzailearen egunkariaren bitartez.

\subsection{Testuingurua}

Ikerketa hau Villabonako Dr. Fleming eskola publikoan egin dugu; Haur eta Lehen Hezkuntzako D ereduko ikastetxea da. Haur Hezkuntza herrian bertan dago eta Lehen Hezkuntza, beste eraiki batean, mendi aldean. Gaur egun, bi lerroko ikastetxea da, 11 irakasle aritzen dira lanean Haur Hezkuntzan (HH) eta 18, Lehen Hezkuntzan (LH). Denera, batez beste, 35 irakasle aritu dira lanean ikasturtean zehar, lanaldi osoak eta murriztuak kontuan harturik.

Aipatzekoa da, halaber, oso urte gutxitan etorkinen ehunekoa izugarri aldatu dela, batez ere, HHn. Duela 8 urte ia zero izatetik, \%22 izatera pasatu da gaur egun. Lehen Hezkuntzako ehunekoa, txikiagoa da, \%9,7 eta eskola osoa kontuan harturik, \%14,8.

\subsection{Partaideak}

Ikerketan, 24 irakaslek parte hartu zuten hasieran. Berez, klaustro osoak parte har zezan pentsatuta zegoen arren, badira saio horietan parte hartu ez duten zenbait irakasle, lanaldi murriztua edukitzeagatik, lanorduak beste zereginetan eman behar izateagatik, edota ni neu, ikertzailea izanik, parte hartu ezin izategatik.

Hogeita lau partaide horien artean, 18k dute han plaza finkoa; beste 3, oposaketak gaindituta, haien lanpostua eskuratu gabe daude eta, oraingoz, eskolan finkatu dituzte; eta falta diren beste 3ak, ordezkoak izanik, printzipioz urte beterako etorriak ziren. Horietako 8 Haur Hezkuntzako irakasleak dira eta gainerakoak, Lehen Hezkuntzakoak. Horietako 17, tutore eta besteak (7), espezialistak (Gorputz Hezkuntzako, musikako, ingeleseko, Pedagogia Terapeutikoko irakasleak, HHko laguntzailea eta administrazio-lanak egiten dituen irakaslea).

Hona hemen irakasle horien lan esperientzia eta eskolan emandako urteei buruzko informazioa, taula batean adierazita. 
1. taula

Partaideen profila

\begin{tabular}{lccccc}
\hline \multicolumn{7}{c}{ IRAKASLEEN LAN-ESPERIENTZIA (urteetan) } \\
\hline ETAPA & $20>$ & $20<15$ & $15<10$ & $10<5$ & $5<1$ \\
HH & 4 & 2 & 2 & & \\
LH & 5 & 9 & 1 & 1 & \\
\hline \multicolumn{7}{c}{ ZENTROAN EMANDAKO URTEAK } \\
\hline ETAPA & $20>$ & $20<15$ & $15<10$ & $10<5$ & $5<1$ \\
HH & 4 & 1 & 4 & 4 & 7 \\
LH & & &
\end{tabular}

Iturria: norberak egindakoa

Argitu behar da, halaber, saio guztietan ez dutela beti 24ek parte hartu zenbait arrazoirengatik. Bestalde, saioren batean, bajan zeuden irakasleen ordezkoek ere parte hartu izan dute unean-unean.

\subsection{Ikerketaren diseinua eta planifikazioa}

Lanaren planifikazioak, I-Ek eskatzen duen espiral formako prozesuaren lehen borobila ixtera iritsi ahal izateko (Kemmis eta Netasgart, 1998; Elliot, 1989; Car eta Kemmis, 1988) eta hurrengoaren hasiera markatzeko, zenbait fase egin dira: diseinua aurkeztea eta onartzea, ikerketa planifikatzea, prestakuntza-saioak, prestakuntzaren ebaluazioa eta etorkizunari begirako jarraipena. Hemendik aurrerako prozesuak eskema berari jarraituko dio, malguki baten espiralen antzean. Hona hemen, era grafikoan eta modu ulergarriagoan adierazita, gauzatu den prozesuaren nondik norakoa. Urdinez agertzen diren geziek lehen aipatutako espiralaren lehen borobilaren faseak irudikatzen dituzte eta laranjaz agertzen direnek, berriz, bigarren borobilaren hasiera:

- Lehen fasea: Diseinua aurkeztea eta onartzea (Gaia aukeratzea)

2012-2013 maiatzaren hasieran, klaustroak onartu zuen proposamena (inplikazioa lortzeko ezinbesteko) eta, 2013-2014ko Ikastetxeko Urteko Planaren barruan, jasota geratu zen: «El cambio educativo en la enseñanza sólo puede darse si el profesor se implica en el proceso de reflexión sobre su práctica.» (Pérez Gémezek, 1999: 461. or.).

- Bigarren fasea: (Ikerketa planifikatzea) 
Jakinda aldaketak espero zitezkeela, printzipioz ordu eta erdiko 6 saio aurreikusi genituen eta irakasleak 8 lagunez osatutako 3 taldetan banatu genituen. Carek eta Kemmisek (1988) azaltzen duten eran, plan globala diseinatuta, ikerketaren lehen pausoa ezarrita zegoen.

- Hirugarren fasea: Prestakuntza-saioak (Planari ekiteko ekintza kritikoki informatua aukeratzea; kritikoki informatutako ekintzaren ondorioei behatzea eta hausnarketa)

Ikerketa 2013-2014 ikasturtean zehar egin genuen, urritik maiatzera. Azkenik, 9 saio egin ziren, betiere saio guztietan zehar lehenik bakarkako lana eta ondoren, taldearena sustatuz. Modu horretan ziurtatu dugu denon iritzia jasota gelditzen dela. Era berean, saio bakoitzean, aurrekoan lortutako datuak aurkeztu dira eta amaieran, balorazioa jaso.

Hirugarren fase horrek lehen aipatutako I-Eren zikloaren barruko urratsak hartzen ditu, saio bakoitzak ziklo oso bat osatu baitu, espiral handiaren barruko azpiespiral gisa funtzionatuz. Hona hemen taula moduan aurkeztuta egindakoaren laburpena:

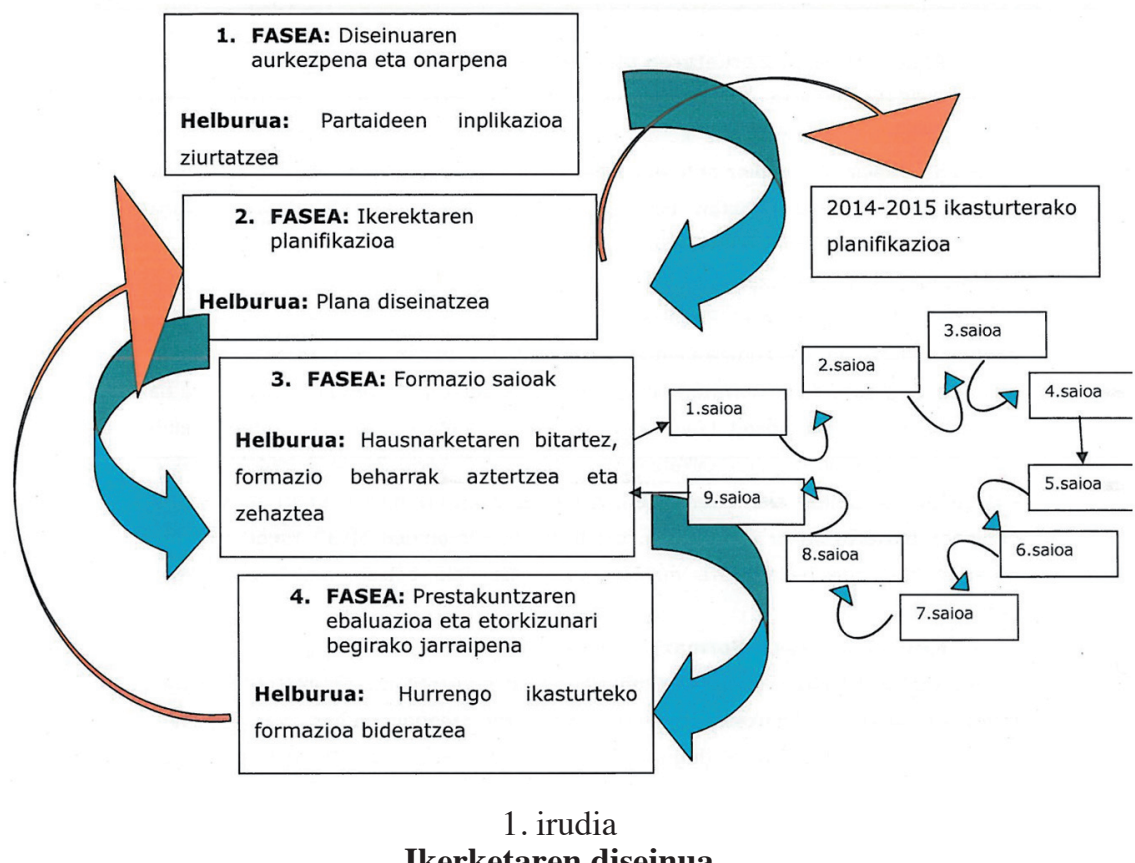

Ikerketaren diseinua

Iturria: norberak egina 


\section{2. taula}

\section{Prestakuntza-saioen laburpena}

\begin{tabular}{|c|c|c|}
\hline SAIOA & HELBURUA & PROZEDURA \\
\hline $\begin{array}{l}\text { 1. Zinema-Foruma } \\
\text { ( } 3 \text { talde txiki) }\end{array}$ & $\begin{array}{l}\text { Ramón Flechari egindako elkarrizketa (te- } \\
\text { lebistatik grabatua) oinarri hartuta, informa- } \\
\text { zioaren gizarteak ekarri dizkigun aldaketen } \\
\text { inguruko hasierako hausnarketa (ideiak piz- } \\
\text { tea, motibatzea, aldaketaz jabetzea, taldea- } \\
\text { ren kohesioa, interakzioa) eragitea. }\end{array}$ & $\begin{array}{l}\text { Elkarrizketa entzun bitartean esangu- } \\
\text { ratsuak gertatu zaizkien ideia pare bat } \\
\text { apuntatu, banaka azaldu, kategorien ara- } \\
\text { bera multzokatu eta horien inguruan hitz } \\
\text { egun. }\end{array}$ \\
\hline $\begin{array}{l}\text { 2. Ikasle ideala } \\
\text { ( } 3 \text { talde txiki) }\end{array}$ & $\begin{array}{l}\text { Nolako ikasleak lortu nahi genituzkeen } \\
\text { pentsatzea eta azaltzea. }\end{array}$ & $\begin{array}{l}\text { Bakarka, zenbait iruditan oinarrituta lor- } \\
\text { tu nahi genituzkeen ikasleen ezaugarriak } \\
\text { aukeratu eta, gero, bikoteka, lau adostu. } \\
\text { Hori adierazten duten argazkiak atera eta } \\
\text { taldeari egindako lana aurkeztu. }\end{array}$ \\
\hline $\begin{array}{l}\text { 3. Autobiografia } \\
\text { (Bakarka) }\end{array}$ & $\begin{array}{l}\text { Bizitza profesionalean zehar garrantzi- } \\
\text { tsuak gertatu zaizkien hiru gertakari, bi- } \\
\text { zipen, esperientzia... idatziz azaltzea.. }\end{array}$ & $\begin{array}{l}\text { Idazketa mekanikoa erabiliz (forma zain- } \\
\text { du gabe eta ideiak etorri ahala idatzi), } 3 \\
\text { une esanguratsu idatziz azaldu. }\end{array}$ \\
\hline $\begin{array}{l}\text { 4. Ariketa aztertzea } \\
\text { ( } 3 \text { talde txiki) }\end{array}$ & $\begin{array}{l}\text { Ikasleekin praktikara eramandako ariketa } \\
\text { bat aztertzea eta hobetzeko proposame- } \\
\text { nak iradokitzea. }\end{array}$ & $\begin{array}{l}\text { Banaka eta eskema bati jarraituz, egindakoa } \\
\text { eta hobekuntza proposamenak idatzi. Talde } \\
\text { osoari azaldu eta ideia berriak iradoki. }\end{array}$ \\
\hline $\begin{array}{l}\text { 5. Praktika onak } \\
\text { (HH eta LH) }\end{array}$ & $\begin{array}{l}\text { EHUk balio erantsiko ikastetxeetako } \\
\text { praktika onen inguruan egindako ikerke- } \\
\text { taren emaitzak aztertzea. }\end{array}$ & $\begin{array}{l}\text { Banaka kategoria bat aukeratu eta han da- } \\
\text { goena ulertu. Gero, bikoteka jarrita, infor- } \\
\text { mazioa trukatu eta jartzen duena adostu. }\end{array}$ \\
\hline $\begin{array}{l}\text { 6. Prestakuntza-mota } \\
\text { (3 talde txiki) }\end{array}$ & $\begin{array}{l}\text { Nolako prestakuntza behar genukeen ere- } \\
\text { dura hurbildu eta horri buruz hausnartzea. }\end{array}$ & $\begin{array}{l}\text { Imbernonen kapitulu baten inguruko ter- } \\
\text { tulia dialogikoa. }\end{array}$ \\
\hline $\begin{array}{l}\text { 7. DAFO } \\
\text { (Talde handia) }\end{array}$ & $\begin{array}{l}\text { Lortutako emaitzez osatutako kategorien } \\
\text { azterketa eginez, gure prestakuntza-beha- } \\
\text { rrei antzeman ahal izateko eskolako egoe- } \\
\text { raren diagnostikoa (indarguneak, ahulgu- } \\
\text { neak, aukerak eta mehatxuak) egitea. }\end{array}$ & $\begin{array}{l}\text { Praktika onen ikerketaren emaitzen ka- } \\
\text { tegorizazioan oinarrituta, gure saioetan } \\
\text { zehar bildutako datuak sailkatu; aurrena, } \\
\text { bakarka, eta talde txikitan adostu ondo- } \\
\text { ren; DAFOn kokatu. }\end{array}$ \\
\hline 8. DAFO & $\begin{array}{l}\text { Gure prestakuntza-beharrei antzeman } \\
\text { ahal izateko, eskolako egoeraren diag- } \\
\text { nostikoa (ahulguneak eta aukerak) egi- } \\
\text { tea, DAFOa osatuz. }\end{array}$ & $\begin{array}{l}\text { Txantiloietan jasota zegoen informazioa } \\
\text { aztertu ondoren, taula batean kokatuta } \\
\text { eman eta hori talde txikitan banatuta, az- } \\
\text { tertu; besteei azaldu eta, denon artean, } \\
\text { DAFOa nola geldituko den adostu. }\end{array}$ \\
\hline $\begin{array}{l}\text { 9. Talde nominala } \\
\text { (Talde handia) }\end{array}$ & $\begin{array}{l}\text { Gure prestakuntzarako baliagarriak diren } \\
\text { ahulezi eta aukeretan oinarrituta, beha- } \\
\text { ren lehentasuna adostea. }\end{array}$ & $\begin{array}{l}\text { Beharrak zenbakituta aurkeztuta, bakoitzak } \\
\text { bat aukeratu, talde homogeneoak osatu eta } \\
\text { behar horren lehentasuna arrazoitzeko ar- } \\
\text { gumentuak adostu talde txikitan. Gero, tal- } \\
\text { de osoari azaldu, eztabaidatu eta talde no- } \\
\text { minala dinamika erabiliz, bat aukeratu. }\end{array}$ \\
\hline
\end{tabular}

Iturria: norberak egina 
Egindakoa hobeto uler dezaten, uste dut komeni dela espazioak uzten duen neurrian, azaldutakoaren zenbait adibide erakustea: saio baten antolaketa, horietan jasotako egunkaria eta kategorizazioaren ondorioz sortutako emaitzen orri bat.

IKASLEEKIN EGINDAKO ARIKETA:

4. SAIOREN ANTOLAKETA: Informatika gelan 16.30etan

Proposatzen ditugun ariketen inguruko hausnarketa

\begin{tabular}{|c|c|c|c|}
\hline EKINTZA & PROZEDURA & MATERIALA & DENBORA \\
\hline $\begin{array}{l}\text { Aurreko } \\
\text { ondorioak, } \\
\text { saioaren } \\
\text { prozedura eta } \\
\text { helburua } \\
\text { azaldu }\end{array}$ & $\begin{array}{l}\text { Azken hamabost } \\
\text { egunetan, zozketaz } \\
\text { egokitu den arlo bat } \\
\text { kontuan harturik, } \\
\text { ikasleekin } \\
\text { burututako ariketa } \\
\text { baten azterketa } \\
\text { sakona egiteko } \\
\text { txantiloia nola bete } \\
\text { azaldu. }\end{array}$ & $\begin{array}{l}\text { Aurrekio } \\
\text { ondorioak } \\
\text { Egokitutako } \\
\text { arloak }\end{array}$ & $\begin{array}{l}5 \text { minutu } \\
(5 \mathrm{~min})\end{array}$ \\
\hline $\begin{array}{l}\text { Fitxaren } \\
\text { hasierako } \\
\text { zatia betetzea }\end{array}$ & $\begin{array}{l}\text { Txantiloia bete: } \\
\text { ariketa burutu } \\
\text { aurretik kontuan } \\
\text { hartutako atalak }\end{array}$ & Fitxaren kopiak & $\underset{(25 \mathrm{~min})}{20 \mathrm{~min}}$ \\
\hline $\begin{array}{l}\text { Hobetzeko } \\
\text { proposamenak }\end{array}$ & $\begin{array}{l}\text { Ariketa bakoitza } \\
\text { hobetzeko } \\
\text { proposamen } \\
\text { atalean, iradokizun } \\
\text { bat idatzi atalik } \\
\text { ahulenetik hasita. }\end{array}$ & $\begin{array}{l}\text { 2. zutabean hobe } \\
\text { daitezkeen } \\
\text { proposamenak } \\
\text { egin, bakoitzak } \\
\text { bere ariketan } \\
\text { pentsatuta, } \\
\text { jakinda orokor } \\
\text { daitekeela. }\end{array}$ & $\begin{array}{l}15 \mathrm{~min} \\
(40 \mathrm{~min})\end{array}$ \\
\hline $\begin{array}{l}\text { Talde handian } \\
\text { aurkezpena }\end{array}$ & $\begin{array}{l}\text { Egindako lana } \\
\text { taldekideei azaldu } \\
\text { (prozedura, } \\
\text { antolaketa, } \\
\text { prestaketa, } \\
\text { helburuak...) banan } \\
\text { bana. }\end{array}$ & $\begin{array}{l}\text { Betetako } \\
\text { txantiloia beste } \\
\text { taldekideei } \\
\text { proiektuaren } \\
\text { bidez erakutsi. }\end{array}$ & $\begin{array}{l}40 \text { min }(5 \\
\text { minutu } \\
\text { bakoitzak) } \\
(80 \text { min })\end{array}$ \\
\hline $\begin{array}{l}\text { Hobetzeko } \\
\text { konpromisoa }\end{array}$ & $\begin{array}{l}\text { Antzeko lanak } \\
\text { plantatzerakoan, } \\
\text { hobe daitekeen arlo } \\
\text { bat aukeratu eta } \\
\text { horretarako } \\
\text { konpromisua hartu. }\end{array}$ & & $\begin{array}{l}5 \min \\
(85 \min )\end{array}$ \\
\hline $\begin{array}{l}\text { Saio } \\
\text { Itxiera }\end{array}$ & Saioaren balorazioa & & $\begin{array}{l}5 \text { minutu } \\
(90 \mathrm{~min})\end{array}$ \\
\hline
\end{tabular}

2. irudia

4. saiorako prestatuko aurkezpen fitxa

Iturria: norberak egina 


\section{ARIKETA AZTERTZEN}

\section{4-01-13}

Saio honetan ez dut uste jakin dudanik lana argi azaltzen eta denbora ez dut batere ondo kontrolatu.

Saioa hasi bezain pronto, ariketaren zergatia azaldu nahi izan diet, aurreko saioetatik ateratako ondorioekin lotuz. Ondoren, norberak aukeratutako ariketa azaldu du. Momentu horretan egin behar genuen lanaren zentzua ez dut aurkitu, baina txantiloia betetzen hasi eta gero, lasaitu naiz eta gustura ikusi ditut lanean, pentsatzen. Hor lasaitu naiz, baina orduan konturatu naiz ez diedala garbi azaldu hor idatzi behar zena ariketa egin aurretik haiek planifikatutakoari buruz zela eta ez, egindakoari buruz. Fase horrek uste baino denbora gehiago eskatu digu.

Gero, lehen zutabean idatzitakoa besteei azaltzeko eskatu diet eta orduantxe konturatu naiz genuen

denborarekin ezinezkoa zela; beraz, zuzenean, bakoitzak bere lanean bigarren zutabea betetzeko esan diet eta ordenagailuan gordeta, nik eskuratuko nuela.

Beraz, hurrengorako ariketa zeren inguruan egin behar den eskatuko diet eta zuzenean jarriko ditut lanean, gero bigarren zutabeari buruz hitz egiteko denbora izan dezagun.

Balorazioa egitean urduri nengoelako-edo, ez dut uste «animograma» izeneko teknika argi azaldu dudanik. Komenigarria izan daiteke diagrama kartesiarraren ideia aipatzea: alderdi batean, norberaren asebetetze maila, eta bestean, taldearen inplikazioa.

Nire hanka-sartzea onartu behar izan dut eta, hurrengoan, bi gauza hartu beharko ditut kontuan: ataza garbi azaldu, lan pertsonala osatu zuzenean, eta, ondoren, komunean jarri.

\section{4-01-15}

Oraingo saio honetan, gauzak hobeto joan dira denbora aldetik, baina, hala ere, ordu eta erdian ondo burutu ezin daitekeen ariketa bat da. Sentsazioa da hanka-motz gelditzen dela. Gainera, ez dakit azaltzen egin behar dena edo egin beharrekoa oso arrotz gertatzen zaie, eta ez dute asmatzen egin beharrekoarekin.

Balorazioa egiterakoan, ideia horiek agertu dira, eta nik ere nirea egin dut: badakit ez dagoela denborarik, baina positiboa da konturatzea hori normalean ez dugula egiten eta horren beharra sumatzea, horrek lagunduko baitu gure beharrak zein diren detektatzen.

Nik uste dut ariketa horren helburuak horixe behar duela izan eta ez zertan sakondu behar dugun zehatz-mehatz detektatzea.

\section{4-01-20}

Haur Hezkuntzako saioa izan da. Hasi aurretik, beste taldeetan bezala, aurreko saioetako ondorioak zein ziren azaldu diet eta ariketarekin lotura egin. Nire ustez, beste taldeei emandako azalpena baino argiagoa izan da. Esan diet, agian, Lehen Hezkuntzako ikuspegitik egina zegoela eta haien koordinatzaileari erakutsi niola beraren oniritzia edo ekarpenak jasotzeko. Hala ere, eta adinaren arabera gauzak alda zitezkeen, ikusten zutenean atalen batek ez zuela zerikusirik haien errealitatearekin hutsik uzteko. Ba... talde horrekin, gauza bera gertatu zait.

Oro har, esan daiteke ez dutela ulertu eta lekuz kanpo ibili dira betetzeko eskatzen zitzaizkien itemekin.

Hiru saio hauek eginda, hiruretan gutxi gorabehera, akats bertsuak gertatu direla ikusirik, bururatzen zaidan lehen ondorioa hauxe da (argi dago denbora ez zela nahikoa): haien eskemak eta nik proposatutako lana oso urruti daudela, hau da, behin ere ez dutela pentsatu ariketa baten atzetik egon daitekeen prestakuntza tamaina horretakoa izan daitekeenik.

\section{3. irudia}

\section{4. saioan zehar jasotako egunkaria}




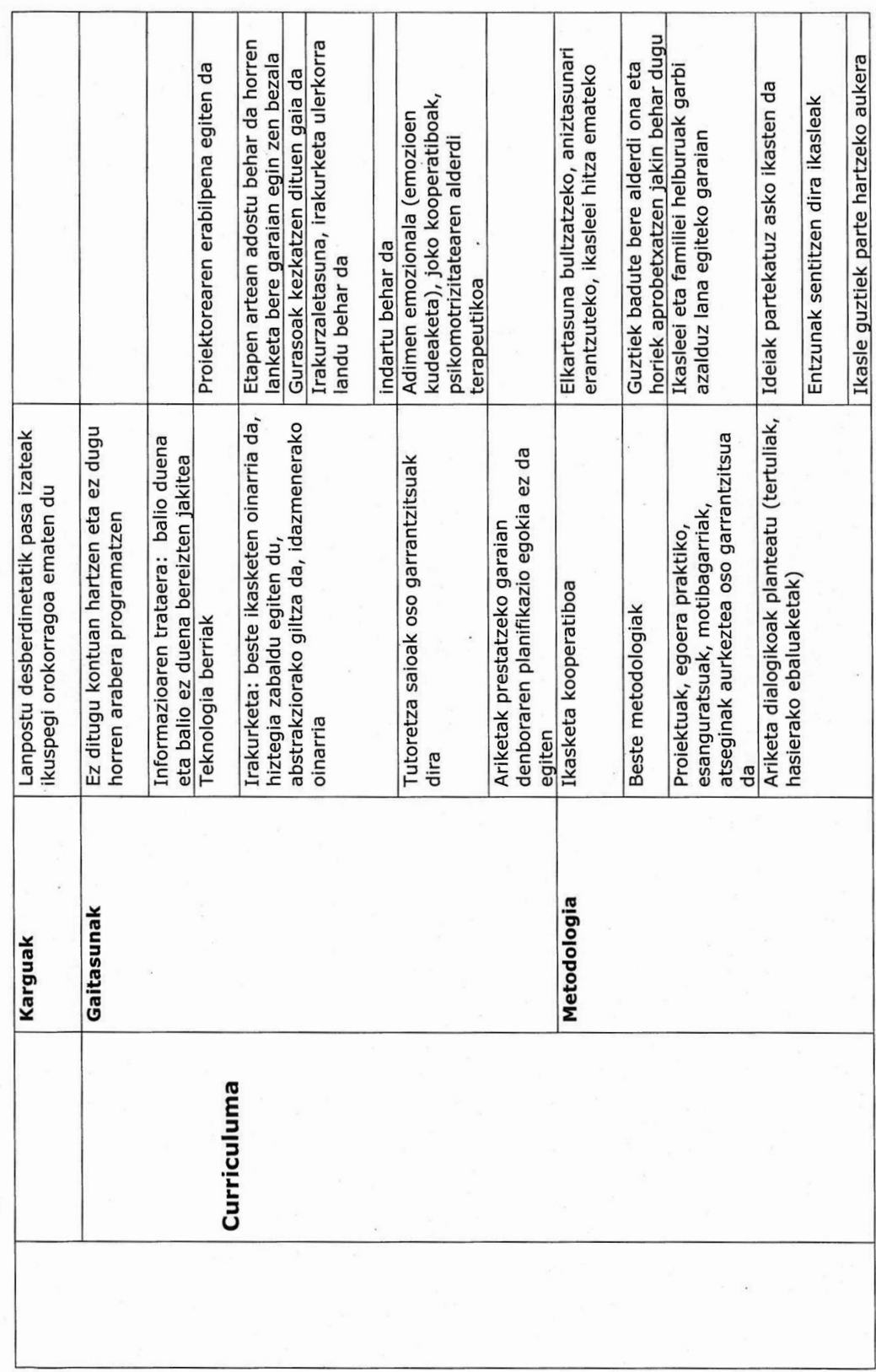

4. irudia

Kategorizazioaren ondorioz sortutako emaitzen orri bat 


\section{- Laugarren fasea: Prestakuntzaren ebaluazioa eta etorkizunari begirako jarraipena (emaitzen analisia eta interpretazioa)}

Atera ziren emaitzekin eta ondorioekin, 2013-2014 Ebaluazio Diagnostikoak eskatzen duen Hobekuntza Esku Hartze Plana osatu zen, nahiz eta hura zehazteko ikerketaren emaitzak iturri bakarra ez den izan, eta horren bitartez, hurrengo ikasturterako (2014-2015) prestakuntza-plana adostuta gelditu zen.

\subsection{Datuak biltzeko estrategiak}

Prozesu osoan zehar, bi estrategia erabili dira datuak biltzeko:

- Prestakuntza-saioak: Proposatutako saioak prestakuntzarako tresna izateaz gain, datuak sortzeko estrategia ere izan dira, horixe bilatzen baitu Ikerkuntza-Ekintzak (Villar, 1995; Kemmis eta Netasgart, 1998; Sandin, 2003). Gainera, saio horietatik lortutako datuak hurrengoak planifikatzeko oinarria izan dira, eta, horiei esker, I-Ek lehen aipatutako espirala (Kemmis eta Netasgart, 1998; Elliot 1989) osatzeko urratsak eman ahal izan dira. Datu horiek biltzeko, zenbait teknika erabili ditut:

- Telebistatik grabatutako elkarrizketa baten bideoa, zine-foruma martxan jartzeko; esandako guztia grabaketaren bitartez jasota geratu zen.

- Irudi batek iradokitzen duenari buruzko azalpena grabatu.

- Partaideek idatzitako autobiografia.

- Txantiloia, ikasleekin egindako ariketa baten inguruko informazioa jasotzeko.

- Aditu baten artikuluaren inguruko tertulia grabatu.

- Osatutako kategorizazioa aztertu eta ahozko adierazpenak grabatu

- DAFOa osatzeko txantiloia.

- Talde nominala izeneko dinamikaren bitartez jasotako ahozko zein idatzizko adierazpenak.

- Egunkaria: saio bakoitzaren amaieran, egunkaria osatu dut, datu gehiago biltzeko tresna gisa. Egunkariak informazio gehigarriaz emateaz gain, ikerketaren prozesuaren inguruko hausnarketarako tresna baliogarria izan zait (Flick, 2002). Han, besteak beste, saio horietako gertakariak (denek parte hartu duten, aldez aurretik egin beharrekoa egina ote zegoen...), nire eginkizunaren ebaluazioa (gidatze-lana, nire parte-hartzea, emozioak....), saioaren nire ebalua- 
zioa (prozedura, denboraren kudeaketa, taldekatzea...), sortutako zalantzak, hurrengo saiorako proposamenak bildu nituen

\subsection{Datuen analisia}

Datuen analisirako, sistema kategoriala (Flick, 2002) erabili dut. Jasotako informazioa kontzeptu orokorretan laburbiltzearen eta haien arteko harremanak ezartzeko prozesuaren emaitza izan da hori. Prozesu horren ondorioz, 3 kategoria eta, bakoitzaren barruan, hainbat dimentsio sortu dira.

\subsection{Datuen balioztatzea}

Jasotako datuak balioztatzeko, bi metodo edo estrategia erabili ditut. Lehena komunikazioaren bitartez bideratutakoa da, eta, hala, saio bakoitzaren hasieran, aurrekoan bildutako kontzeptuak azaltzen dira, eta bigarrena triangulazio metodologikoa izan da, hau da, datuak biltzerakoan, prestakuntza-saioetan zehar, oso metodologia desberdinak erabili dira, bakar bat erabiltzeak ezar ditzakeen mugak gainditu ahal izateko.

\subsection{Alderdi etikoa}

Lan honetan zehar, etikari eta konfidentzialtasunari dagokionez, garrantzitsua da zuhurtziaz jokatzea, irakasleek nahi dutena adierazteko aske senti daitezen, hortaz eta beharrezkoa izan denean, haien baimena ziurtatu da eta haien anonimatua bermatzeko ahotsak kodifikatuta.

\section{EMAITZAK}

Egin ditugun saio guztietan zehar lortu diren datuak aztertzetik ateratako emaitzak hiru kategorietan daude bilduta: Gizartea, Hezkuntza-Komunitatea, Eskola; Eskola; eta Prestakuntza. Kategoria bakoitzean, hainbat dimentsio agertzen dira.

\subsection{Gizartea, Hezkuntza-Komunitatea, Eskola}

Kategoria honen barruan, eskolan eragina duten inguruko eragileekin eta faktoreekin lotutako ideiak daude jasota. 


\subsubsection{Balioak}

Oro har pentsatzen dute gizarteak eta eskolak sustatzen dituzten balioak guztiz kontrajarriak direla eta gizarteak bere burua zuritzeko tresna gisa erabiltzen duela.

\subsubsection{Gizarte modernoaren ezaugarriak}

Irakasleek esaten dute gizartearen aldakortasuna dela eta eskolaren jarduna behar bezala moldatzeko astirik ez dagoela, eta, hori dela eta, inprobisazioa da nagusi.

Argi ikusten dute gaur egun informazio gehiegi dagoela eta hori kudeatzen jakitea dela erronka nagusia. Era berean, teknologia berriek kezka sortzen dute, dagoeneko arlo horretan zenbait ikaslek irakasleek baino gehiago dakitelako.

Aniztasuna. Inklusioaren printzipioa dela eta, gero eta heterogeneoagoak diren ikasleekin egin behar da lan, eta ez dakite horri, teoriak aldarrikatzen duen aberastasunari, etekina ateratzen. Ikasle etorkinek zailtasun bereziak sortzen dituzte: hizkuntza-arazoak (ikasleekin eta haien familiekin komunikatu ahal izateko), kulturen eta ohituren arteko talka, baita egonkortasun falta ere (edozein unetan joan eta etorri egiten dira).

Irudiaren garrantzia. HHko zenbait irakaslerentzat, oztopo bihurtu da hiru zentzutan: teknologia berriek lagunduta, indarra hartu dute esanahiari edo edukiari garrantzia kenduz; forma zaintzeko lan horiek egiteak beste lan batzuk egiteko denbora kentzen du; eta, azkenik, ikasgelak apainduegi daude, eta hori dela eta, baliteke ikasleak gehiegi estimulatuta egotea.

\subsubsection{Besteen inplikazioa}

Ikusten da gizarteak bere gain hartu behar lituzkeen hainbat funtzio eskolari egokitzen zaizkiola eta eskakizun maila gero eta altuagoa dela. Bestetik, esaten dute gizartearen izaerak ekarri dizkigun erronka berriei eskolak bakarrik ezin diela aurre egin, eta, beraz, uste da denon inplikazioa beharrezkoa dela: instituzioak, familiak, irakasleak.

Inplikazio horren bila joateko eta laguntza jasotzeko bi modu aipatu dira. Lehena, gizartea eskolara ekartzea (gurasoak, herriko jendea...). Hori laguntzeko tresna izan daitekeen arren, beldurra sorrarazten du, eta, lan hori sistematizatzeko, zailtasunak ikusten dira. Bigarrena eskola gizartera eramatea da, hau da, herrian dauden errekurtsoak erabiltzea.

\subsection{Eskola}

Oro har esan daiteke ikastetxeko irakasleek pentsatzen dutela gauzak egiten dituztela, saiatzen direla eta aldaketak egiten direla, baina batzuetan 
ez dutela garbi zergatik edota nora begira egiten diren eta beharrezkotzat jotzen da eskolako norabidea argitzea.

\subsubsection{Eskola ideala}

Eskolako giroa oso faktore garrantzitsutzat jotzen da, batez ere irakasleen artekoa eta ikasleekikoa Era beran, uste dute eskolako giroa egokia dela eta zaindu egiten dela.

Irakasle batek izan behar lituzkeen ezaugarrien artean, norberaren ahuleziak ezagutzea eta horiek onartzea aipatu dute, baita ausarta, pazientziaduna, langilea eta estrategiaduna izatea ere. Lortu nahi lituzketen ikasleen ezaugarriak definitzerakoan, honela laburbil daitezke: ikasle zoriontsuak, autoestimu maila egokia dutenak, ausartak, autonomoak, trebetasun sozialak dituztenak, espiritu kritikodunak, langileak eta jakinmina dutenak.

\subsubsection{Eskolako antolaketa}

Kategoria honen barruan, lan egiteko eran erabiltzen duten edo erabil zezaketen antolaketarekin lotutako atalak daude.

\section{- Koordinazioa}

Koordinazioari eman behar zaion garrantzia azpimarratu dute eta agerian geratu da horretan ematen den denbora oso txikia dela. Koordinazio falta horri zenbait mailatan antzematen zaio:

Etapen arteko koordinazioa: HHren eta LHren artean ez dago behar bezalako koordinaziorik, eta honako ondorio hauek agertu dira: gurasoei mezu kontrajarriak helarazten zaizkie, zenbait lan errepikakorrak gertatzen dira, eta etapen arteko trantsizioa ez dago adostuta. Bi etapei ildori beretik jarraitzeko eta adosteko beharra ikusten da.

Zikloen arteko koordinazioa: gertatzen diren aldaketak direla eta, planteamendu pedagogikoez hitz egiteko aukerarik ez dago eta inprobisatuz joaten dira. Irakasleek adierazi dute ziklo bakoitzean zer landu behar den argi definitu behar litzatekeela.

Pedagogia Terapeutikoko (PT) irakaslearekin: aniztasunari erantzun egokiagoa emateko, koordinazio hori hobetu behar litzateke.

Beste esparruetako langileekiko koordinazioa: heziketa ikasgelatik kanpo ere gertatzen da, jangelan, autobusean... Ikasleen jarraipena behar bezala egiteko, esparru horiek hartu behar lirateke kontuan.

Oro har ikusten da ezinbestekoa dela dagoen denbora ondo kudeatzea benetako beharretan emateko; horretarako, lehentasunak 
zein diren garbi eduki behar da. «Lo urgente no deja tiempo a lo importante» esaten zuen irakasle batek.

\section{- Karguak}

Ardura-karguetatik pasatzeak (zuzendari, ikasketaburu, idazkari, jangela arduradun...) eskolako ikuspegi orokorragoa hartzen laguntzen du eta uste dute mesedegarria dela.

\subsubsection{Curriculuma}

Atal honetan, klaseak emate zuzenarekin lotutako alderdiak daude jasota.

\section{- Gaitasunak}

Curriculumaren ardatza izan arren, ez dira behar bezala kontuan hartzen eta ez da horien arabera programatzen, besteak beste, praktikan zertan datzan eta zer suposatzen duten garbi ez dagoelako.

Horien barruan, informazioaren trataera, bereziki, oso garrantzitsutzat jotzen da.

Teknologia berriak ia aipatu ez den gaia da. Atal horren inguruan, hiru ideia agertu dira: proiektorea maiz erabiltzen dela; interneten topa dezakegula izugarrizko informazioa; eta ikasleek guk baino gehiago dakitela.

Irakurketaren inguruan, orain dela urte batzuk, hausnarketa sakona egin zuten, eta, erabakiak hartu zituzten arren, praktika onak galduz joan dira, irakasleria aldatuz joan delako transmisioa ziurtatu gabe, eta, geroztik dauden irakasleek inertziak bultzatuta, zergatia oso argi izan gabe, egiteko era aldatuz joan direlako.

Gaur egungo errealitateari erreparatuta, irakasle talde handi batek aldarrikatu du irakurketaren lanketak prestakuntzaren gunea izan behar duela: ikasketa guztien oinarria delako, irakasleek irakurketaren lanketa egokia nola egin ez dakitelako, irakurzaletasuna lantzea garrantzitsua delako, irakurketaren bidez hizkuntza lantzen delako, abstrakzio maila zabaltzen delako, idazketa lantzeko lagungarria delako eta etapen arteko funtzionamendua adostu behar delako.

Tutoretza-saioak irakasleen egitekoaren alderdi positibotzat hartzen dituzte. Oro har, garrantzi handia ematen zaie han lantzen diren edukiei (adimen emozionala, joko kooperatiboak, psikomotrizitatearen alderdi terapeutikoa). Dena den, zenbait irakaslek tutoretzarako dagoen saioa ordutegiko aurreko arloetako lanak bukatzeko erabiltzen dute.

\section{- Metodologia}

Atal honi dagokionez, zenbait alderdi aipatu dira: 
Ikasketa kooperatiboa; dagoeneko erabiltzen da (ez \%100 eta erritmo desberdinekin), eta oso baliogarritzat jotzen da elkartasuna lantzeko, aniztasunari erantzuteko eta ikasleei hitza emateko. Hala ere, batzuen ustez, metodologia guztiek badute beren alderdi ona eta horiek uztartu behar lirateke.

Proiektuak, egoera praktiko eta esanguratsuak planteatzea ikasleen beharretatik abiatuz, lanak motibagarriak eta atseginak suertatzen dira, eta ikasteari zentzua ematen dio horrek, baina ez da hala egiten.

Haien ustez, ariketa dialogikoak oso egokiak dira, ideiak partekatuz asko ikasten delako, irakasleak entzun dituela sentitzen dutelako ikasleek eta denek parte hartzeko aukera ematen duelako, baina, gaur egun, oso gutxitan erabiltzen dira.

\section{- Aniztasunaren trataera}

Kezka handia sorrarazten du gai horrek, eta ez dakite teorikoek honi ikusten dioten abantailari etekina nola atera. Gehienetan, talde osoko erritmo moteltzera jotzen da. Horri erantzuteko, zenbait baliabide eta estrategia aipatu dira:

Zailtasunak dituzten ikasleei begira PTarekin koordinazioa hobetzea, piktogramak erabiltzea, gela arrunteko edukiak aldez aurretik lantzea, ulermena ziurtatzeko beste estrategiak (irakurketa-aurrea, ahozko azalpenekin batera egin beharrekoa antzeztea, azalpena beste ikasle bati errepikatzeko eskatzea) erabiltzea...

Pertsona bat baino gehiago gela barruan egotea baliogarritzat hartzen da. Beste irakasle bat izan daiteke, praktiketako ikasleak, ikasle-ikasketak bukatu dutenak edota guraso zein herriko jendea. Kanpoko norbait ekartzea zailagoa iruditzen zaie.

Ikaskideez eta ikastaldeaz baliatzea: gela bereko ikasleez baliatzea, ohikoak ez diren (adina kontuan hartu gabe) taldekatzeak erabiltzea, ikasketa kooperatiboa eta talde dinamika lantzea ere proposatu egiten da.

\section{- Ebaluazioa}

Ebaluazioa ez da maiz agertu den gaia; hala ere, ez dirudi ebaluatzearen eta zuzentzearen arteko desberdintasunak argi daudenik. Ohartzen dira beti ebaluazio mota bera erabiltzen dela (irakasleak ikaslea ebaluatzea) eta bestelakoak ere erabil daitezkeela, hala nola koebaluazioa edota ikasleek irakasleak proposatutako ariketak ebaluatzea.

\subsection{Irakasleen prestakuntza}

Ikerketaren muina izanik, atal osotzat agertzen da, lau dimentsiotan banatuta. 


\subsubsection{Orain arte jasotako prestakuntza}

Bizitza profesionalean zehar jasotakoari egiten dio erreferentzia

- Prestakuntza estandarra (aditu batek emandako azalpen magistraletan oinarritutako prestakuntza) ez dute baliogarritzat jotzen. Lehenik, ikastaroak askotan modari jarraituz edo diruari begira hautatzen direlako, eta, interesgarriak izan daitezkeen arren, normalean ez diete eskolako benetako beharrei erantzuten, besteak beste, bakarkakoa izaten delako. Bigarrenik, esperientzia arrakastatsuetan eta arazo potoloen azterketan oinarrituak izaten dira, eta dira bat etortzen eskolako testuinguruarekin; beraz, jasotakoak ez du balio, eta eguneroko arazo txikiek hor diraute. Hori oso desmotibagarria gerta daiteke eta hurrengo ikastaroekiko mesfidantza edo arbuioa sor dezake.

- Bestelako prestakuntza (lan bat diseinatu, praktikara eraman eta azkenik hura aztertu). Garai batean, denontzako eta oso jarraipen zehatzeko prestakuntza jaso zen eskolan (irakurketa-idazketa prozesua konstruktibismoaren ikuspegitik). Horren balorazio oso positiboa da norberaren esperientzia azaltzeko eta hausnartzeko denbora hartzeko aukera eman zuelako. Horrek gauzak zergatik egiten diren jakiteko aukera eman zuen eta, itxurari baino, mamiari erreparatu zioten.

\subsubsection{Ikerketa bitarteko prestakuntza}

Atal honetan, prestakuntzaren inguruko baloraziotik ateratako emaitzak bildu dira, ikerketak iraun bitartean jasoak.

Oro har, esan daiteke hausnarketarako oso tresna baliagarria suertatu zaiela eta oso positibotzat jotzen dutela honako alderdi hauek lantzeko balio izan baitu: hausnarketarako tartea hartu ahal izateko, bakarka egiten ez diren gogoetak egiteko, eskolako egoera hobeto ezagutzeko (dauden hutsuneak, erabiltzen diren tresnak eta metodologia, dauden beharrak), eta gure lanbidearen konplexutasunaz ohartzeko.

Hausnarketaren bitartez, denen iritzia entzun da eta, horri esker, partaidetza bultzatu ahal izan da, ideiak partekatu eta, jomuga bera izanik, denon arteko erabakiak hartu zein ondorio bateratuak lortu eta aurreragoko lanak zehaztu. Prozesu horren bitartez, talde-kohesioa eta inplikazioa areagotu egin dira.

Erresistentziak, ehuneko txikian bada ere, hauteman egin dira, zenbait modutan: aldez aurretik egin beharreko lana egin ez izana, saioetara berandu iritsi, saioetan zehar oso parte-hartze txikia.

Egindako prozesuaren inguruan aipatu behar da, oro har, HHko irakasleek balorazioa ezezkorragoa egiten dutela LHkoek baino. Batzuek, diotenez, ez zaie oso aberasgarria suertatu eta bakarren batek 
pentsatzen du prestakuntza-saiorik egin gabe ere antzeko ondorioetara iritsiko zirela.

\subsubsection{Jaso nahi luketen prestakuntza}

Ikusten dute inertziak bultzatuta funtzionatzen dutela aldaketak gertatuz gero, eta beste zerbait beharrezkoa dela.

Uste dute eskolarako egokia den prestakuntzak honako ezaugarri hauek izan behar lituzkeela. Hasteko, ikasleekin erabiltzen ditugun irizpide berak hartu behar lirateke kontuan: motibazioa, beharretatik abiatzea, aniztasuna... Jarraitzeko, uste dute partaideen esperientzien inguruko hausnarketan eta ideien trukaketan oinarritu behar litzatekeela: esperientzia handiko irakasleak izanik, alderdi praktikoari begira, aditu batek baino gehiago jakin dezaketelako; uste dutelako prestakuntza-saioetan jaso baino eman egin behar dela; pentsatzen dutelako esperientziarekin zein ideien trukaketan asko ikasten dela; egunerokoak diren eta denok ukitzen dituzten egoera zehatzetatik eta kasu praktikoetatik abiatuta, norberaren testuinguruaren araberako irtenbideak behar direlako.

Hala, gauzak zergatik egiten diren jakingo lukete eta aldaketak hausnarketa-prozesu baten ondorioa lirateke, eta ez, inertziak eraginda. Halaber, aipatu dute horrelako jarduerek lanerako gogoa pizten dutela eta ez dela astuna suertatzen (denbora azkar pasatzen da).

Premiazkoa da eskola osorako prestakuntza eta eskolako interesak kontuan hartuta izatea, aldaketak gerta daitezen irakasle guztien inplikazioa behar delako; norberaren interesak alde batera utziz, ikasleen beharrei eta kalitateari begirako prestakuntza planteatu behar litzateke; eta edukia bertako irakasleek adostuta izan behar luke.

Haien aburuz, talde txikietan antolatuta egotea mesedegarria da, lasai hitz egiteko aukera ematen duelako, denon iritzia jasotzen dela ziurtatzen delako eta elkar hobeto ezagutzeko aukera ematen duelako.

Oro har, horrelako prestakuntzak denbora asko eskatzen duela arren, uste dute aurrera begirako inbertsiotzat hartzen da.

\section{- Oztopoak eta irtenbide posibleak}

Oztopo bat baino gehiago ikusten dute. Hasteko, haien ustez, irakasleen egitekoa aldatzea ez da erreza, irakasleok gauzak beste era batera egiten ikasi dugulako eta horrek beldurra sentiaraz diezagukeelako. Bestetik, prestakuntza eraginkorra izan dadin, denbora eman behar da eta horretarako lehentasunak ondo markatzen ikasi behar da. Eta, azkenik, transmisioan dago, eskolako langile guztiak ez baitira finkoak

Horrelakorik gerta ez dadin, ezinbesteko baldintza proiektuan sinestea litzateke eta irtenbide posible bat adostutakoa idatziz jasotzea. 
Uste dute benetako aldaketak gerta daitezen ezinbestekoa dela hezkuntza komunitatearen inplikazioa eta gurasoen laguntza, haien aburuz, hori esparru guztietan agertu behar baita.

\subsubsection{Instituzioen papera}

Instituzioengan ez dago konfiantza handirik, are gehiago, aipatu da autonomia gutxitzen dutela, besteak beste, baliabide ekonomikoak gutxituta lan bera egin behar delako pertsona gutxiagoren artean. Gainera, pedagogiarekin zerikusirik ez dituzten eginkizunak gehitzen dituzte. Horrez gain, haien esanetan, lan egiteko era ere baldintzatzen dute notak, azterketak eta kanpoko ebaluazioak nahitaez ezarriz.

\section{ONDORIOAK ETA EZTABAIDA}

Lehenik eta behin, aipatu behar da ikerketa honek hausnarketarako oso tresna baliagarria izan dela, eta, gainera, horren jarraipena egiteko bidea ireki duela. Nire ustez, oso ona da hori, prestakuntza horrek, marko teorikoan agertu bezala, prestatzen jarraitzeko eta, Dr. Fleming ikastetxea mikro-sistematzat hartuta, auto-aldaketarako tresna bihurtzeko balio izan badu. Azken finean, horixe zen lan honen helburu eta erronka nagusia.

Ikerketan zehar bildutako datuak eta horien azterketatik lortutako emaitzak kontuan hartuz, hona hemen lana bere osotasunean hartuta atera daitezkeen ondoriorik garrantzitsuenak:

- Orokorrenetik hasita, aipatu behar da Dr. Fleming ikastetxeko irakasleen artean gizartearen eta eskolaren arteko harremanarekiko dagoen iritzia ez dela oso baikorra, uste baitute gizarteak bete eta bere gain hartuko behar lituzkeen hainbat ardura, bere burua zuritzeko, eskolari egokitzen dizkiola. Hala, eskolaren eta, horren ondorioz, irakasleen eginkizunak geroz eta gehiago dira (Carbonell, 2006). Gainera, badirudi horiek guztiak eskolak bakarrik bete behar dituela eta argi azaldu dute hori ezinezkoa dela. Garbi aldarrikatu dute ikasleekiko ardurak behar bezala betetzeko denon inplikazioa (irakasleak, gurasoak, herria) beharrezkoa dela (Fullan, 1993; Imbernon 2008; Perrenoud, 2012), baina hori nola egin daitekeen ez dago garbi.

- Eskolako irakasleak konturatzen dira gaur egungo gizartea bestelakoa dela eta aldaketak oso azkar gertatzen direla (Aguerrondo eta Xifra, 2002; Imbernon 2008; Pérez Gómez, 2006; Perrenoud, 2012). Errealitate horri eta erritmo bizian suertatuz doazen behar berriei erantzuteko inprobisazioa da nagusi, ez delako astirik hartzen alor pedagogiko inguruko zalantzak, kezkak, iritziak eta praktikak partekatzeko. Horren ordez, modak-edo agintzen dituen gaiak aukeratzen 
dira; prestakuntza jasotzen da, eta aurretik ikasitakoa baztertu egiten da, zergatik gertatu den jakin gabe. Argi azaldu dute hori saihestu beharreko jokaera dela eta erabakiak hartzen (praktikak mantendu edo alboratu) horren inguruko hausnarketa egiteak lagundu egingo duela. (Stenhouse, 1985, 1987; Elliot, 1989; Schön, 1992; Villar, 1995; Marcelo, 1995; Pérez Gómez, 1999, 2006, 2010; Imbernon, 1995, 2008; Contreras, 2010; Korthagen, 2010; Perrenoud, 2012...).

- Aldaketa horiek eraginda ikasleengan gaitasunak garatzeko beharra ikusten den arren, klaustroak ez du garbi zertan datzan edo nola landu behar diren. Aipamen nabarmenenak informazioaren kudeaketarekin lotutakoak izan dira (Pérez Gómez, 2006). Praktikan ikusi ahal izan dute ikasleek informazioa pila bat ekartzen dutela, baina gero ez dakitela horrekin zer egin. Era berean, ikasketa esanguratsua eta errealitatean oinarritutakoaren garrantzia aipatu den arren, oihartzun handirik izan ez duen puntua suertatu da.

- Aurrekoaren ondorioaren inguruko hausnarketatik sortu da beste kezka bat: denboraren kudeaketa. Irakasleek pentsatzen dute lehentasuna ez duten lanetan ematen dutela beren denbora (jangelako kudeaketan, materiala oso txukun prestatzean...) eta ikusten dute benetan garrantzia duten gaiak eta kezkak beren horretan geratzen direla. Horrek gabezia handiak sortzen ditu, adibidez, Haur Hezkuntzaren eta Lehen Hezkuntzaren arteko loturan, zikloen arteko jarraipenean eta, oro har, adostutako erabakiak hartzerakoan. Horren eraginez, bakoitzak ahal duena egiten du. Hausnarketa horretatik ondorioztatu dute denok batera nola jokatu adosteko denbora hartu behar dela lehentasuna zerk duen argi izanda eta iparra galdu gabe.

- Ikasleen aniztasunak kezka sortzen du, etorkinei begira (Imbernon, 2008) HHn batez ere, eta ikasleen erritmoa errespetatzerakoan, batik bat LHn. HHn kanpotik etorritako ikasleen mugimendu handiagoa dago. Konturatu dira ohitura eta kultura desberdinek elkar ulertzea zaila dela; hizkuntza oztopo bihurtzen da familiekin zein haurrekin komunikatzeko, eta familia horien ezegonkortasunak eskolako erritmoa hausten du. LHn, ordea, badakite ikasle bakoitzaren erritmoa errespetatzea garrantzitsua dela, baina, nahiz eta ahaleginak egiten diren, denak berdin tratatzea da joera. Heterogenotasun hori aberastasun-iturria izan daiteke (Courtney, 2013), baina irakasleek ez dakite horri etekina ateratzen.

- Orain arte azaldutako funtzionamenduak nolabaiteko egonezina sortzen du, esaten dute gauzak egiten direla eta lanpetuta ibiltzen direla, ikasi beharreko gauza berriak etortzen direla eta aurretik egiten zirenak existituko ez balira bezala funtzionatzen dutela, eta berri horiek oraindik sendotu gabe daudela, berriagoak iristen direla. Ikusi da horrek frustrazioa sortzen duela eta hori marko teorikoan aipatutako desprofesionalizazioarekin lotzen dut (Carbonell, 2006). Ideia 
hori honela adierazten zuen irakasle batek: «Bai, baina, batzuetan, lehen egindakoa ez da aintzakotzat hartzen. Batzuetan ematen du egoera berriak datozela, eta egindako guztia existituko ez balitz bezala jokatzen dugu eta gauzak ez dira horrela.»

- Aipatu dutenez, jaso nahi duten prestakuntza ikastetxean kokatuko behar litzateke, betiere denen artean topatutako beharrei erantzuteko, baldin eta eskola gisa benetako aldaketak lortu nahi badira (Imbernon, 2008; Marcelo, 1995; Pérez Gómez, 2010; Contreras eta Pérez de Lara, 2010). Bakarkako prestakuntzak ez du hori lortzeko aukerarik ematen. Gainera, bertako irakasle asko esperientzia handikoak dira eta pentsatzen dute dakiten horretatik abiatuta, haien praktikak partekatuz, oso prestakuntza egokia lortuko litzatekeela eta lanerako motibazioa handituko litzatekeela (Imbernon, 2008; Pérez Gómez 2010).

- Hurrengo ikasturteari begira prestakuntzaren gunea zein izango den zehaztuta gelditu da: irakurketa. Alde batetik, ikusten da eskolan lantzen den oinarrizko eduki eta prozedura dela, eta, bestetik, eskola osoa, modu desberdinean bada ere, harrapatzen duela. Hala, praktikaren hausnarketa-prozesua gidatuko duen unibertsitateko irakasle batekin, zenbait saio eta horien prozedura adostu dira, eta, alderdi teorikoari begira, Berritzeguneko aholkulari batek laguntzeko konpromisoa hartu du. Beraz, hurrengo ikasturteko irakasleen prestakuntzari dagokionez, irakurketa gaia ardaztzat hartuta, planifikatuta gelditu da, ikerketa honek erakutsi dituen zenbat alderdi kontuan harturik: prestakuntza ikastetxean bertan kokatuko da, adostutako beharretatik abiatuz; praktikaren eta teoriaren arteko zubia aurreikusten da; norberaren lana hobetzeko, haien errealitatean eta ideien trukaketan oinarritutako prozedura zehaztu da (Stenhouse, 1985, 1987; Elliot, 1989; Schön, 1992; Villar, 1995; Marcelo, 1995; Pérez Gómez, 1999, 2006, 2010; Imbernon, 1995, 2008; Contreras, 2010; Korthagen, 2010; Perrenoud, 2012 ...).

\section{ESKER ONA}

Lehenik eta behin, eskerrak eman nahi dizkiet nire lankide guztiei. Alde batetik, konpromisoa, inplikazioa eta lanarekiko jarrera ezin hobea erakutsi dutelako. Itxurakeria alde batera utzita, benetako errealitatea islatzeko ahaleginak egin dituzte, ahuleziak eta indarguneak agerian utziz. Bestetik, eskertu behar dut, halaber, zuzendaritzak eman didan laguntza, prozesuan zehar suertatu diren behar berriei moldatzeko erakutsi duten prestutasunagatik. 


\begin{abstract}
One of the main characteristics of the present information society is the change and the uncertainty of what the future may bring. School must prepare students to face new situations, but, despite the different measures taken to this end (educational reforms, laws, permanent training...), the results haven't been fully as expected. The basis for success lies in taking the teachers into account and offer them another kind of training. Therefore, the school centre, the teachers' experience, reflection and collegiality must be the main point of focus. But the implication of the teachers is essential here, and this research wants to become the starting point to achieve this commitment. In order to analyse and detect the training needs, at Dr. Flemming Educational Centre, we have completed the first step of the cycle that the action research requires, basing it on the school itself, reflection, collegiality and collaboration.
\end{abstract}

Keywords: Action Research, training, reflection, Primmary School

Una de las principales características de la sociedad de la actual sociedad de la información es el cambio y la incertidumbre de lo que el futuro nos puede deparar. Es deber de la escuela preparar al alumnado para poder hacer frente a esa situación, y, aunque los intentos han sido varios (reformas educativas, leyes, formación continua...), el resultado no ha sido el esperado. La base para asegurar logros está en tener en cuenta al profesorado y en ofrecerle otro tipo de formación. Ésta debe pasar por tener en cuenta el centro, la experiencia del profesorado, la reflexión y la colegialidad. Pero para ello, la implicación de los docentes es esencial objetivo que esta investigación persigue. Así, con el objetivo de analizar y detectar las necesidades formativas de la escuela Dr. Fleming, hemos desarrollado un proceso basado en el centro, en la reflexión, en la colegialidad y en la colaboración, llegando a completar el primer paso del ciclo que la Investigación-Acción exige.

Palabras clave: Investigación-Acción, formación, reflexión, colegialidad, Educación Infantil y Primaria

L'une des principales caractéristiques de la Société de l'Information actuelle est le changement et l'incertitude concernant le futur. L'école doit préparer les élèves à faire face aux nouvelles situations, mais malgré les différentes mesures prises à cet effet (réformes de l'éducation, lois, formation continue...), les résultats 
n'ont pas comblé les attentes. La base de la réussite réside dans la prise en compte des enseignants et dans le fait de leur offrir un autre type de formation. Par conséquent, le centre scolaire, l'expérience des enseignants, la réflexion et la collégialité doivent être les principaux points de mire. Mais, l'implication des enseignants est essentielle ici, et cette recherche souhaite devenir le point de départ afin de réaliser cet engagement. Dans le but d'analyser et de détecter les besoins de la formation, au Dr. Flemming Centre Educationnel, nous avons terminé la première étape du cycle que la recherche-action nécessite basé sur l'école elle-même, la réflexion, la collégialité et la collaboration.

Mots-clé: Recherche-action, formation, réflexion, école primaire

\section{ERREFERENTZIAK}

Aguerrondo, I. eta Xifra, S. (2002). Las escuelas del futuro I. Cómo piensan las escuelas que innovan. Buenos Aires: Papers.

Car, W. eta Kemmis, W. (1988). Teoría crítica de la enseñanza. La investigaciónacción en la formación del profesorado. Barcelona: Martínez Roca.

Contreras-Domingo, J. (2010). «Ser y saber en la formación didáctica del profesorado: una visión personal». Revista Interuniversitaria de Formación del Profesorado, 68 (24,2), 61-81.

Contreras-Domingo, J. eta Pérez de Lara, N. (2010). Investigar la experiencia educativa. Madrid: Morata

Carbonell, J. (2006). «Rasgos que caracterizan o identifican la crisis de los docentes». In La reforma necesaria: Entre la política educativa y la práctica escolar. Madrid: Morata.

Courtney, C. (2013). «Los mejores resultados se obtienen con la diversidad». Cuadernos de pedagogía 437 (36-41).

Díaz Tezanos, E. (2006). «La reforma posible y necesaria». In La reforma necesaria: Entre la política educativa y la práctica escolar. Madrid: Morata.

Europako Kontseilua/Consejo Europeo de Lisboa 23 y 24 de marzo 2000. Conclusiones de la presidencia. Helbide honetan: http://www.europarl.europa.eu/ summits/lis1_es.htm\#6 (2014-03-02an kontsultatua)

Europako Parlamentua. Europar Parlamentuaren eta Kontseiluaren 2006/962/ EE Gomendioa, 2006ko abenduaren 18koa, etengabeko ikaskuntzarako funtsezko gaitasunei buruzkoa [Aldizkari Ofiziala L 394 de 30.12.2006]. Helbide honetan: http://eur-lex .europa.eu/legal-content/ES/TXT/HTML/?uri=CELEX: 32006H0962\&from=ES (2014-03-02n kontsultatua)

Euskal Autonomia Erkidegoko Oinarrizko Hezkuntzaren curriculumaren dekretua: Euskal Herriko Agintaritzaren Aldizkaria - 2010eko apirilaren 20koa, asteartea 72. zk. 
175/2007 Dekretua, urriaren 16koa, Euskal Autonomia Erkidegoko Oinarrizko Hezkuntzaren curriculuma sortu eta ezartzekoa. Euskal Herriko Agintaritzaren Aldizkaria 2007ko urriaren 16a, 218. zk.

Elliot, J. (1989). Investigación/acción en el aula. Valencia: Generalitat Valenciana.

Flick, U. (2002). Introducción a la investigación cualitativa. Madrid: Morata.

Fullan, M. (1993). Las fuerzas del cambio. Explorando las profundidades de la reforma educativa. Madrid: Akal.

Gimeno-Sacristán, J. eta beste zenbait (2006). «De las reformas como política a las políticas de reforma». In La reforma necesaria: Entre la política educativa y la práctica esoclar. Madrid: Morata.

Imbernon, F. (1994). La formación y desarrollo profesional del profesorado: $\mathrm{Ha}$ cia una nueva cultura profesiona. Barcelona: Graó.

Imbernon, F. (2008). 10 ideas clave. La formación permanente del profesorado. Barcelona: Graó.

Kemmis, S. eta Mc Taggart, R. (1998). Cómo planificar la investigación-acción. Barcelona: Laertes.

Korthagen, Fred A.J. (2010). La práctica, la teoría y la persona en la formación del profesorado. Revista Interuniversitaria de Formación del Profesorado, 68 $(24,2), 83-101$.

Marcelo-García, C. (1995). Formación del profesorado para el cambio educativo. Bartzelona: EUB.

Pérez-Gómez, A.I. eta beste zenbait (1999). Desarrollo profesional del docente. Política, investigación y práctica. Madrid: Akal.

Pérez-Gómez, A.I. (2006). A favor de la escuela educativa en la sociedad de la información. La reforma necesaria: Entre la política educativa y la práctica escolar. Madrid: Morata.

Pérez-Gómez, A.I. (2010). «Reinventar la profesión docente, un reto Inaplazable». Revista Interuniversitaria de Formación del Profesorado, 68 (24,2), 61-81.

Perrenoud, P. (2012). Cuando la escuela pretende preparar para la vida. Barcelona: Graó.

Puelles, M. (2006). «Los hitos reformistas: La viabilidad de las reformas y la perversión de las leyes». In La reforma necesaria: Entre la política educativa y la práctica escolar. Madrid: Morata.

Rodríguez, G.; Gil, J.eta García, E. (1996). Metodología de la investigación cualitativa. Málaga: Aljibe.

Sandín, M.P. (2003). Investigación cualitativa en educación: Fundamentos y tradiciones. Madrid: McGraw-Hill/interamericana de España.

Sancho, J.M.; Correa, J.M. (2013). «Apender a ser maestra: perplejidades y paradojas». Cuadernos de pedagogía 436 (18-22).

Santos-Guerra, M.A. (2010). «La formación del profesorado en las instituciones que aprenden». Revista Interuniversitaria de Formación del Profesorado, 68 $(24,2), 61-81$.

Schön, D. (1992). La formación de profesionales reflexivos. Hacia un nuevo diseño de la enseñanza y el aprendizaje en las profesiones. Madrid: Paidós.

Stenhouse, L. (1984). La investigación como base de la enseñanza. Madrid: Morata.

Stenhouse, L. (1987). Investigación y desarrollo del curriculum. Madrid: Morata. 
Valls, R.; Soler, M.; Flecha R. (2008). «Lectura dialógica: interacciones que mejoran o aceleran la lectura». Revista iberoamericanda de educación, 68, 71-87.

Villar, L.M. (eta batzuk) (1995). Un círculo de enseñanza relfexiva. Bilbao: Mensajero.

Zabala, A. (2012) «Prólogo a la edición española: ¿Tenemos otra opción que no sea preparar para la vida?». In PERRENOUD (2012). Cuando la escuela pretende preparar para la vida. Barcelona: Graó. 